\title{
The Polish Elites' Struggle for Recognition of the Experience of Communism in the European Union
}

\author{
Magdalena Góra and Zdzistaw Mach
}

The course of history placed Poles outside the reflections on the shape of the political processes in Western Europe after the Second World War. Nevertheless, the origins of various Polish concepts and visions of the country's place in Europe can be traced back to the 15th and 16th centuries and the Golden Age of the Jagiellonian Commonwealth. Throughout the difficult years of their troubled history, the Polish elites referred to Western Europe as an important cultural source and a civilisation they belonged to. It was also during the period of Communism that - especially for the democratic opposition - Western Europe was a source of inspiration and resources. ${ }^{1}$ Europe, particularly Western Europe, was then to Poles a very significant point of reference and one which was essential for their collective identity. Whether as a paradise of wealth and higher level of consumption, for Poles who dreamt of a better life, or as a land of freedom and high culture, for those Poles who had more intellectual and cultural ambitions, Western Europe was a dreamland, on the other side of the Iron Curtain, accessible only sporadically on occasions of infrequent tourist or professional visits. When Communism ended in Poland and Central and Eastern Europe (CEE), Poles eagerly and almost immediately declared their intention to 'return to Europe'. Western Europe, or simply 'the West', as it was then commonly referred to, was seen in Poland as a largely undifferentiated, homogenized area of freedom, democracy and prosperity. Little was known about the internal diversity of Western Europe, and even less about the different problematic issues related to collective memory, sensitivities and conflicts of interpretation of European history. An example of the difficult lessons of European conflicts of attitudes and interpretations which Poles had to learn was the experience of the war against Iraq in 2003, in which some EU member states supported the USA, while others refused to participate in the invasion. In the decision of the latter group, anti-American sentiments played an important

1 Magdalena Góra and Zdzisław Mach, "Between Old Fears and New Challenges. The Polish Debate of Europe", in European Stories. Intellectual Debates in National Contexts, ed. Justine Lacroix, Kalypso Nicolaïdis (Oxford: Oxford University Press, 2010).

(C) MAGDALENA GÓRA AND ZDZISŁAW MACH, 2017 | DOI 10.1163/9789004352353_004

This is an open access chapter distributed under the terms of the CC-BY-NC License. 
role. Poles had to understand that they might have to take sides and choose between different Western countries, which, before 1989, were seen from the Polish perspective as the unified 'West'. The situation also stressed the importance of how the actions of political actors were perceived and received by Western counter partners, and it displayed the interactivity of European politics.

The research on the debate on the future of Europe highlights the fact that it has seemed very difficult for Poles, both ordinary people and intellectuals, to think in terms of a common, European 'we.' ${ }^{2}$ European interests were previously not perceived as being equal to Polish interests and solidarity did not extend beyond national borders. Poles tend to think of the EU predominantly from a national point of view. The $\mathrm{EU}$ is good if and when it contributes to Poland's strength, prosperity and security. One might say that Europe is seen in Poland as an instrumental value, not a value in itself. A pro-European position considers European integration as good for Poland, while an anti-European approach believes that European integration deprives Poland of values essential for its identity and well-being - mainly political sovereignty, tradition and Roman Catholicism (identified here as the essence of Polishness). At the same time, however, Poles express high levels of optimism as regards the $\mathrm{EU}$, and the European component is crucial for the Polish collective identification.

The focus of this chapter is on how the experience of Communism still shapes the behaviour of Polish elites and politicians and how they use the memory of Communism in order to claim recognition within the EU. How has the specific historical experience of Communism influenced the reflection on Europe, identification with Europe and perception of this political project in Poland? How have political actors in the EU perceived such claims? The eastern EU enlargement has challenged the established Western European notions of the memory of the Second World War and particularly the insignificance of the Communist crimes vis-à-vis those of the Nazi regime. As Maria Mälksoo claims "in spite of the institutional unification of the "two halves of Europe" after the end of the Cold War, the consolidation of the legacy of the Second World War in general, and that of the Soviet regime in Eastern Europe in particular, is long overdue. Europe has remained divided when it comes to the political, moral, and legal evaluation of the criminal inheritance of the other totalitarian tradition in the history of the twentieth century - that of Soviet Communism.' ${ }^{3}$ The problem with the recognition of the totalitarian nature of Soviet Communism

2 Góra, Mach, Between Old Fears; Magdalena Góra, "Solidarity of Citizens and of States in the European Union", Visegrad Insight 2:4 (2013).

3 Maria Mälksoo, "The Discourse of Communist Crimes in the European Memory Politics of World War II", (paper presented at the Ideology and Discourse Analysis conference 
and its crimes in CEE has already attracted attention, even though it still raises many controversies. In this chapter we will use the concept of recognition in order to analyze how it is utilized for political purposes in everyday European politics. The concept of recognition allows capturing the dialogical nature of the processes in European politics and focus not only on the claimants but also on the reception of claims.

In the following sections we will first provide a theoretical background of our analysis and present the concept of recognition and its role in contemporary European politics. In the second part we will explain how the memory of Communism and historical politics has functioned on the domestic level in Poland. In the final part we will present the analysis of debates from the European Parliament, where claims for recognition of the historical experience of Poland have stirred up fervent debates.

\section{Recognition, Collective Identity, Redistribution and Collective Memory}

Since the 1960 s scholars dealing with the functioning of contemporary societies have been increasingly focusing on the concept of recognition. The process of recognition is a crucial element of one's subjectivity and a foundation of a process of identification understood in relational terms when the other is necessarily involved in a mutual relationship. According to Charles Taylor's observation, 'our identity is partly shaped by recognition or its absence, often by the misrecognition of others, and so a person or group of people can suffer real damage, real distortion, if the people or society around them mirror back to them a confining or demeaning or contemptible picture of themselves. Nonrecognition or misrecognition can inflict harm, can be a form of oppression, imprisoning someone in a false, distorted, and reduced mode of being' ${ }^{4}$ Recognition is therefore relational and dialogical in its nature. The reception of the claims for recognition and response to it matters. Recognition is not only about 'an expectation of the confirmation of abilities and value by the other, ${ }^{5}$ it is also about socialization and social integration 'through the regulated forms

'Rethinking Political Frontiers and Democracy in a New World Order', Roskilde University, Denmark, 8-10 September 2008), 1.

4 Charles Taylor, "The Politics of Recognition", in Multiculturalism. The Examination the Politics of Recognition, ed. Amy Gutman (Princeton, New Jersey: Princeton University Press, 1994), 25.

5 Christian Lazzeri and Alain Caillé, "Recognition Today. The Theoretical, Ethical and Political Stakes of the Concept", in Recognition, Work, Politics. New Directions in French Critical Theory, ed. Jean-Philippe Deranty et al. (Leiden, Boston: Brill, 2007), 92. 
of recognition'. ${ }^{6}$ Recognition allows us then to grasp the nature of legitimized social order being such 'only to the degree that they [societies] are in a position to guarantee reliable relations of mutual recognition at various levels'. Therefore, in the increasingly diverse societies of Western Europe, the concept of recognition has become a tool to better grasp the dynamics of relationships between various groups: ethnic and national minorities (also immigration groups), women, sexual minorities etc. Ultimately, it is worth mentioning that the thinkers who introduced and developed the concept of recognition also had a normative idea in mind, namely how to build a just, modern society. ${ }^{8}$ In this regard, the concept of recognition 'defines the conditions of a just society through the aim of recognizing the individual dignity of all individuals. ${ }^{9}$

This normative aspect has led to the emergence of the politics of recognition at least since the 196os, defined as a need to deal with the existence of multiple identities and recognition of the diversity of belongings in the contemporary world. ${ }^{10}$ The issue of recognition becomes central in contemporary societies and assumes that it is 'a complex multilateral web of relations and their affects among actors of different types'.1 This multiplicity of dimensions and actors in turn has resulted in the introduction of the concept of recognition order, understood as 'a framework within which individuals and groups are learning to see themselves as recognised with respect to certain characteristics'. ${ }^{12}$ The recognition order was firstly conceptualized and analyzed within nation state frames of reference and in such a context the politics of recognition was mostly analyzed.

The politics of recognition deals with the question of how domestic institutions such as schools, universities, mass media, health care institutions and the army respond to and accommodate the necessity of the recognition of diverse social composition. ${ }^{13}$ It results in an important dilemma of politics of

Axel Honneth, "Recognition and Justice: Outline of a Plural Theory of Justice", Acta Sociologica 47:4 (2004), 354 .

7 Ibid.

8 Ibid.

9 Ibid, $35^{2}$.

10 Axel Honneth, The Struggle for Recognition: The Moral Grammar of Social Conflicts (Cambridge: Polity Press, 1995); Taylor, "The Politics".

11 James Tully, "Struggles over Recognition and Distribution", Constellations 7:4 (2001), 474.

12 Axel Honneth, "Redistribution as Recognition: A Response to Nancy Fraser", in Fraser N., Honneth A., Redistribution of recognition? A political-philosophical exchange (London, New York: Verso, 2003) quoted in John Erik Fossum, "Conceptualizing the EU's Social Constituency", European Journal of Social Theory 8:2 (2005), 125.

13 Amy Gutman, "Introduction", in Multiculturalism. Examining the Politics of Recognition, ed. Amy Gutman (Princeton, New Jersey: Princeton University Press, 1994). 
recognition, stressing that in principle the public sphere should be 'difference blind' in order to fulfil the principle of recognition. ${ }^{14}$ Introducing reflection in the politics of recognition allows one to reconsider the fundamental condition on which contemporary liberal democracy is built in the context of increasingly diverse societies. This reflection is especially potent in the context of the politics of recognition entering the supranational arena, particularly within the EU. This will be developed further in the next section.

However, the politics of recognition also highlights the important aspect of redistribution, as famously raised by Nancy Fraser and debated with Honneth. ${ }^{15}$ Social movements demanding recognition - such as the women's or African American rights movements - have also focused on more just redistribution. Fraser argues that these are 'two dimensions of justice' in contemporary societies that need to be addressed. She claims, 'it is my general thesis that justice today requires both redistribution and recognition, as neither alone is sufficient.'. ${ }^{16}$ In order to establish what the relationship between them is, Fraser makes the assumption that recognition is a matter of justice: 'One should say, rather, that it is unjust that some individuals and groups are denied the status of full partners in social interactions simply as a consequence of institutionalized patterns of interpretation and evaluation in whose construction they have not equally participated and that disparage their distinctive characteristics or the distinctive characteristics assigned to them. ${ }^{\prime 7}$ As a consequence, misrecognition is a social phenomenon, which influences the position in social relations including the redistribution. Fraser therefore proposes a bivalent conception of justice, which 'does not treat recognition as a good to be distributed, nor distribution as an expression of recognition. Rather, a bivalent conception treats distribution and recognition as distinct perspectives on, and dimensions of, justice, while at the same time encompassing both of them within a broader, overarching framework. ${ }^{18}$ We argue that the main link between the two is through identity. ${ }^{19}$ As we have already stated above - the recognition is about including various narratives in mainstream collective identification and treating them as just and appropriate. Similarly, including certain groups

14 Taylor, "The Politics", 40.

15 Nancy Fraser and Axel Honneth, Redistribution of recognition? A Political-Philosophical Exchange (London, New York: Verso 2003).

16 Nancy Fraser, "Social Justice in the Age of Identity Politics: Redistribution, Recognition, and Participation", (the Tanner Lectures on Human Values. Delivered at Stanford University 30 April-2 May 1996), 5 .

17 Ibid., 24.

18 Ibid., 30.

19 Honneth, "Redistribution". 
in mainstream identification processes equips them with the legitimization to claim for redistribution. This two-dimensional aspect of recognition claims is connected with identity-oriented elements and economic demands within the recognition order and will serve as the theoretical basis for analyzing the aims of the recognition claims of Polish political actors within the $\mathrm{EU}$.

The debates on the politics of recognition have also entered the supranational level, especially in the context of the European integration. Scholars argue that, at least since the beginning of the 1990s, the politics of recognition developed mainly within the national framework has also entered the supranational level..$^{20}$ This is connected with the growing significance of policy-making and redistribution within the EU. Therefore, argues John Erik Fossum, the EU can become a new, broader recognition order if citizens and political actors seek recognition not only in the nation states but also in supranational arenas. ${ }^{21}$ Fossum also argues that this may lead to the creation of the EU as a social constituency, meaning that the EU will develop beyond a merely functional order and will transform into a full-fletched polity, especially for its citizens. According to him, this transformation has already started, as was specifically visible during the $2004 \mathrm{EU}$ enlargement. After the enlargement of the EU, new political actors from CEE started to express their particular, historically determined and hegemonic (in terms of distribution of power) demands of equal recognition. ${ }^{22}$ The new claims and new perspective brought by MEPs from CEE regarding the recognition of the Christian elements of European identity and politics could serve as an example. ${ }^{23}$

Such demands for recognition within the Eu serve several purposes. Firstly, they focus on the recognition of certain collective identifications within European mainstream narrative and as a result claim belonging to the European community. In the context of this chapter, political actors from CEE demand recognition of their unique historical experience of the Second World War and Communism in order to receive equal status in the EU. Secondly, derived from the identity-oriented aspect of recognition, the demand allows actors to claim fair redistribution within the EU political system. It is an especially important

2o Zenia Hellgren and Barbara Hobson, "Gender and ethnic minority claims in Swedish and EU frames. Sites of Multilevel Political Opportunities and Boundary Making”, in Gender politics in the expanding European Union: mobilization, inclusion, exclusion, ed. Silke Roth (New York, Oxford: Berghahn Books, 2008).

21 Fossum, "Conceptualizing".

22 Ibid.

23 Magdalena Góra and Katarzyna Zielińska, "Defenders of faith? Victims of secularization? Polish politicians in the European Parliament”, Religion, State, Society 42:2-3 (2014). 
aspect because within the EU new injustices may emerge and, as a result, a new axis of conflict could form. ${ }^{24}$ The important aspect of the claims for recognition is their reception. It is a dialogical, interactive construction where the success of the claimant depends on whether or not claims are received as legitimate. Therefore it is crucial not only to look at the claimants but also at the reception of the claims.

The specific aspect of theoretical debate on recognition concerns the role of the past experience of groups in their demands for recognition and redistribution. Various groups claim the recognition of their unique historical experience and heritage. As Carlos Closa puts it, 'Recognition of memory in a given community restores persons' dignity by means of policies which take into account their claims. Recognition thus is an essential component of policies of memory and politics of memory are the struggles for recognition of memory claims.25 It is an old dilemma in democratic societies how to recognize various, different and often contradicting narratives of past experiences and how to deal with the attempts to falsify history. Especially in CEE, strong conflicts of memory frequently arise. ${ }^{26}$ This is especially significant due to the role of memory in shaping dominant collective identifications in contemporary societies. In the European context, political actors from CEE demand recognition of their experience and suffering. According to this concept, if Europeans want to construct collective identity on equal terms, various historical experiences - also those of Communism - must be taken as equally valid. As Carlos Closa states, 'in the view of its [equal recognition] proponents, the dominant narrative on European history (as reflected by education, symbolic practices and awareness initiatives) reflects predominantly (and for some only exclusively) the experiences of the Western part of the continent whilst the historical experience of Central and Eastern European countries has not been included.' ${ }^{27}$ Maria Mälksoo, on the other hand, has stressed that the CEE actors make "vocal claims of "equal subjectivity" in the European mnemopolitical field as well as reverberate their increasing sense of confidence about the

24 John Erik Fossum and Marit Eldholm, "Conceptualising (and tentatively mapping) the Eu's social constituency", in Civic Resources and the Future of the European Union, ed. Ireneusz Pawel Karolewski, Viktoria Kaina (London: Routledge, 2012).

25 Closa, "Negotiating the Past", 6.

26 Siobhan Kattago, "Memory, Pluralism and the Agony of Politics", Journal of Baltic Studies 41:3 (2010); Georges Mink and Laure Neumayer, History, Memory and Politics in Central and Eastern Europe. Memory Games (Basingstoke: Plagrave Macmillan, 2013). 
density of their ties to the Euro-Atlantic security community'.28 Both scholars link 'equal' claims to the sense of belonging in community along the lines of recognition theory.

There is growing research on the content of these claims. Closa lists several elements raised in the European public sphere when equal recognition is demanded. The dominant demands are for condemnation of the communist regimes: the criminalization of the denial of so-called totalitarian crimes, the recognition of commemoration dates which are linked to facts of memory of CEE countries, and the teaching of history integrating CEE perspectives and finally focusing on memorialization policies. ${ }^{29}$ Mälksoo focuses on the demand for the recognition of the criminal nature of Soviet Communism and the recognition of its crimes as genocide. ${ }^{30}$ Other scholars analyzing the politics of memory of Polish actors on the European level stress three main areas where a unique perspective is used most frequently: the insistence of the commemoration of the Katyn massacre, the specific Polish experience under Communism, and the special relations with Poland's new Eastern neighbours (Ukraine, Belarus and Lithuania). ${ }^{31}$ Recently scholars have also focused on the way political actors from new member states became memory entrepreneurs in order to promote their claims. ${ }^{32}$

During the process of EU accession, one of the most important topics highlighted by Western actors was connected with the narrative on the Second World War. Specifically in the case of Poland it concerned the Holocaust remembrance and the reintroduction to the public discourse of the complicated relations between Poles, Jews and the Nazi and Soviet occupiers. Another topic has covered the forced transfers of population - particularly German - after the Second World War. These attempts were perceived as a Europeanization of the discourse on history in Europe. For years, however, the process of the Europeanization of historical discourse was asymmetrical - the demands were directed mostly at the CEE countries.

28 Mälksoo, "The Discourse", 7 .

29 Closa, "Negotiating the Past".

30 Mälksoo, "The Discourse".

31 Matt Killingsworth, Małgorzata Klatt and Stefan Auer, "Where Does Poland Fit in Europe? How Political Memory Influences Polish me Ps' Perceptions of Poland's place in Europe", Perspectives on European Politics and Society 11:4 (2010).

32 Laure Neumayer, "Integrating the Central European Past into a Common Narrative: The Mobilizations Around the 'Crimes of Communism' in the European Parliament”, in:Journal of Contemporary European Studies 23:3 (2015). 
In this chapter we will look at the other direction of the process of Europeanization of history discourse when political actors from CEE direct certain claims for recognition to and their reception by the Western European actors.

\section{Collective Memory and Historical Politics in Poland after Communism}

Polish national identity, collective memory, political culture and the perception of Europe are a result of Poland's unique location between East and West and specific historical processes. The geopolitical location and strong identification with Western European civilization versus the East have resulted in constant tensions in the region and developed a strong sensitivity towards the past in Poland. ${ }^{33}$ The experience of the Nazi occupation and later of the Communism rule has contributed to the sense of betrayal by the West and strengthened the endangered collective identity.

Since 1989 the issue of dealing with the past has resurfaced. First and foremost, as for previous centuries, the turn to the West as a source of security, modernization and prosperity has become a widely accepted policy priority. The initial political idea of how to deal with the heritage of Communism was the concept of a 'thick line' promoted by the first democratic Prime Minister Tadeusz Mazowiecki. He claimed: 'We split away the history of our recent past with a thick line. We will be responsible only for what we have done to help extract Poland from her current predicament, from now on'. ${ }^{34}$ It was meant to allow the focus to shift more to the current challenges of the devastated country and promote a fresh start. However, it was very soon interpreted as a call for cutting off what had happened before 1989, avoiding de-Communisation and

33 Joanna Pękacz, “'Antemurale of Europe'. From the History of National Megalomania In Poland", History of European Ideas 20:1-3 (1995); Georges Sanford, "Overcoming the Burden of History in Polish Foreign Policy", Journal of Communist Studies and Transition Politics 19:3 (2003); Janusz Tazbir, "Europejska wspólnota obronna”, in Europa. Drogi integracji, ed. Aniela. Dylus (Warszawa: Studium Generale Europa, Uniwersytet Kardynała Stefana Wyszyńskiego, 1999).

34 Tadeusz Mazowiecki, "Wnioski Prezydenta PRL o odwołaniu ze stanowiska Prezesa Rady Ministrów Czesława Kiszczaka oraz o powołanie na stanowisko Prezesa Rady Ministrów Tadeusza Mazowieckiego", in Sejm Rzeczpospolitej Polskiej X Kadencji, Sprawozdanie Stenograficzne z 6 Posiedzenia Sejmu, 23 i 24 sierpnia 1989, Warszawa 1989, accessed August 2014, http://orka2.sejm.gov.pl/StenogramyX.nsf/o/259278CD28DE3BBDC1257D20002CC6 FD/\$file/oo6_ooooo6771.pdf (authors' own translation). 
not punishing those responsible for crimes committed during Communism. Very soon the right-wing parties which emerged from the Solidarity camp started to question Mazowiecki's approach and criticize the Round Table accords as a means for the systemic transition into democracy. They perceived it as a rotten compromise allowing the Communist elites to regain power within the economic realm and they demanded lustration. There were several attempts to pursue this, none of which ever fully succeeded. ${ }^{35}$

At the end of the first democratic decade new political forces such as Prawo i Sprawiedliwość (PiS - Law and Justice), founded in 2001 and based on the previous centre-right wing parties, started to call for a new opening and the pursuit of historical politics in the country. It was a result of the harsh criticism of the first decade of democracy in Poland: 'this project consisted of several clear elements: from the idea of moral pluralism and the neutrality of the state, with the conviction of the imitative nature of the Polish transformation, the recognition of a fast modernisation as a major goal (including cultural modernisation), stemming from the lack of trust and reluctance to the national tradition, the ban on de-communisation and so on. (...) It did not pay much attention to the question of the affirmative sharpening of identity and collective memory'. ${ }^{36}$ So this affirmative shaping of Polish collective memory became a political goal to be pursued on the domestic level. Historical politics became a central element of the political programme of PiS and also became popular among other centre and right-wing parties in Poland. The content of this affirmative shaping concerned predominantly the period of the Second World War and specifically the way relations between German and Soviet occupiers, the Polish population and Jews were interpreted. A good illustration for this wasthe two fierce debates following the publication of the Jan T. Gross books in 2001 and $2006 .^{37}$

35 Natalia Letki, "Lustration and Democratisation in East-Central Europe", Europe-Asia Studies 54:4 (2002); Kieran Williams, Aleks Szczerbiak and Brigid Fowler, "Explaining Lustration in Eastern Europe: 'A Post-communist politics approach”, SEI Working Paper 62 (2003), accessed August 2014 https://www.sussex.ac.uk/webteam/gateway/file .php?name=sei-working-paper-no-62.pdf\&site=266; Lavinia Stan (ed.), Eastern Europe and the Former Soviet Union. Reckoning with the communist past (London: Routledge, 2009).

36 Zdzisław Krasnodębski, Demokracja peryferii (Gdańsk: Wydawnictwo słowo/obraz terytoria, 2005), 8 .

37 Tomasz J. Gross, Neighbours. The Destruction of the Jewish Community in Jedwabne, Poland (Princeton: Princeton University Press, 2001); Tomasz J. Gross, Fear: Anti-Semitism in Poland After Auschwitz. An Essay in Historical Interpretation (Princeton, Oxford: Princeton University Press, 2006). 
The second major focus of historical politics in Poland has been dealing with the legacy of Communism. Apart from the first attempts at lustration in 1992 and $1997 / 8$, the new post-Solidarity government initiated in 1997 the creation of Instytut Pamięci Narodowej (IPN - the Institute of National Remembrance) whose main duty was to gather documents, hold inquiries into Nazi and Communist crimes and to educate people. ${ }^{38}$ The historical politics and IPN itself raised high emotions in domestic politics: 'IPN became a most important, visible and controversial institution of contemporary Poland'. ${ }^{39}$ Yet, the additional goal of historical politics in Poland was directed outside the country, especially at the European institutions and states, with special attention to the European Parliament as the agora of the EU. As the leader of PiS (at that time in opposition) said in a debate on foreign policy in the Polish parliament in 2003:

And the next issues are very important to our status, but our activities are - let's say - not enough, if not non-existent. These are historical issues, the issue of the dignity of our nation; it is how we assess the Second World War, and all this connected with the great liberation from Communism (applause). There is tendency in Europe, not to mention the USA, where it is even stronger, to equal guilt and contributions from this period, also from the period of the Second World War. Recently such a declaration was made by the European Parliament. It is about, let's admit that, treating all equally - all suffered losses, all committed crimes. And on the other hand there is a well-known defamatory campaign against our nation as regards its "involvement", and I use inverted comas here, in holocaust; its alleged co-responsibility for this most horrible crime of the war. Now our actions to prevent this are definitely too weak. We can even talk about the participation in such defamatory actions of some - not of Polish diplomacy but - of Polish elites (applause). We need to be clear and decided, we need to undertake all possible actions in order to prevent it. ${ }^{40}$

Similar statements were made frequently, especially in debates related to the role in the EU and especially about relations with Germany. In 2005, for instance, another leader of PiS stated: 'I want to thank for those very clear and

38 Dariusz Stola, "Poland's Institute of national Remembrance: A Ministry of Memory?", in The Convolutions of Historical Politics, ed. A. Miller, M. Lipman (Budapest: Central European University Press, 2012).

39 Ibid., 48.

40 Jarosław Kaczyński, "Wypowiedź w debacie", in Informacja rządu na temat polskiej polityki zagranicznej w 2003 roku. 4 kadencja, 40 posiedzenie, 2 dzień (22 January 2003), accessed August 2014 http://orka2.sejm.gov.pl/Debata4.nsf (authors' own translation). 
so far unsaid words on the issue of historical truth and on the issue of German responsibility for the crimes committed during the Second World War. If such words were spelled out regularly and firmly, parts of the problems in PolishGerman relations would not be present today'41 Such an approach - to fight for the historically understood dignity and honour of the nation - has a long tradition in Poland. It stems from the gentry which dominated the political culture and difficult past on the one hand, and connects to the vivid memory of the glorious times of the Jagiellonian Commonwealth on the other. What is especially interesting for this chapter is that such an approach has been pursued by significant political actors in Poland not only on the domestic level but also that it also had a very clear connection to the debate on the role of Poland in the Eu on the eve of its enlargement to the East. The peak of the attempts to deal with the past, especially of the Communist legacy, was reached in the first years following the EU enlargement. In 2005, PiS formed a ruling coalition (in office until the pre-term elections in 2007) with the rightwing Liga Polskich Rodzin (LPR - League of Polish Families) as well as the populist Samoobrona RP (SRP - Self-defence). As regards historical politics, the main elements of this government's approach on the domestic level were focused on lustration. A new law was adopted in 2006, amended in 2007 and later rejected by the Constitutional Court. On the international and European level, the main aim was to receive recognition of the totalitarian nature of Communism and actions against the alleged defamation of the Polish nation. It is important to note that such an approach to historical politics was supported by PiS and LPR as well as by other political parties from the centreright wing groups. The second most important party on the Polish political scene, the centre-right wing Platforma Obywatelska (PO - Civic Platform) only partially - especially its conservative wing - subscribed to such an agenda. The left wing and liberal parties and liberal circles openly opposed lustration attempts and were much more cautious about the historical politics coined in the 2005-2007 period. Ultimately, the Polish historical politics which gained attention and strength in domestic politics also become visible in the European arena, especially in the European Parliament which was perceived as an agora of the European Union.

Polish representation in the European Parliament in the 6th and 7 th term in office was the largest among the new member states and consisted of $50-54$ MEPS (depending on the term in office). In both the 2004 and 2009 elections,

41 Kazimierz M. Ujazdowski, "Wypowiedź w debacie", in Informacja Ministra Spraw Zagranicznych o zadaniach polskiej polityki zagranicznej w 2005 roku, 4 kadencja, 96 posiedzenie, 3 dzień (21 January 2005), accessed August 2014 http://orka2.sejm.gov.pl/ Debata4.nsf (authors' own translation). 
centre-right wing and right wing parties won the majority of the votes. The winner of both elections, Po, joined the Group of European People's Party (Christian Democrats) and European Democrats (EPP-ED) together with Polskie Stronnictwo Ludowe (PSL - Polish People's Party). The two other winners in 2004: LPR and PiS joined the right-wing party groups. PiS went for Union for a Europe of the Nations Group (UEN) and remained in this party for the entire term in office, while the LPR at first joined Independence and Democracy Group (Ind/DEM). Yet the party split and the majority of the ten LPR MEPS went to other national formations (mostly PiS) and, as a result, joined UEN in the EP. Similarly SRP split (four MEPS out of six left) as well as PSL (three MEPS out of four left). The left-wing parties joined Group of the Party of European Socialists (PES), and liberal formation Unia Wolności (UW - Freedom Union) joined Group of the Alliance of Liberals and Democrats for Europe (ALDE). During the elections for the 7 th EP (2009-2014) the right-wing (LPR) and populist (SRP) parties did not cross the electoral threshold. Their electorate went mostly to PiS which doubled its result in 2009. PiS joined the newly created European Conservatives and Reformists Group (ECR).

In the following we will provide an analysis of Polish MEPs' interventions in and reception of the 6 th and 7 th EP. In order to do so we have selected 11 debates devoted to topics connected with commemoration of totalitarianism, programmes financing such commemorations etc. However, we have also included debates concerning issues not directly related with collective memory or the past. These are debates focusing on issues connected with solidarity and redistribution in the EU (see Annex 1).

The purpose of this selection was to analyze the claims for recognition in the context of the debates on history and memory, but also in less obvious situations. The relevant claims were analyzed as regards their content (what should be recognized?), the addressee (by whom?) and for what reason (why should it be recognized?). Finally our interest was the reception of the claims. It must be noted, however, that the empirical material limits the way that the responses to the analyzed claims are captured. The plenary debates in the EP allow dialogical exchange of opinions, but the limited time allocated to speakers and the fact that MEPs rarely reappear during the same debate are impinging the interactivity and dialogue between MEPs.

\section{Recognition in European Parliament debates}

An analysis of the debates shows that the focus of Polish MEPs on the recognition of their historical, unique experience was most important immediately after the EU enlargement in 2004. During the 6th term in office of the EP it 
seems that debates on the crimes of Soviet Communism were more frequent and heated. The significance of these issues seems to have faded away in the EP's 7th term in office, although claims for recognition remained important. This is probably because the main purpose of the claims was, for those making them, to find and assert their own position within the EU and confirm their own identity as belonging, although equipped with a different - but equally important - historical experience. That had to change with time, and such claims became less frequent when political actors started feeling more assured in the new institutions. In other words, the discussions in the EU on the past and memory seemed to follow from the enlargement. Moreover it is important to note that the debates were initiated by the memory entrepreneurs from CEE. ${ }^{42}$

The interesting issue remains as to who raised the claims for recognition most often among Polish MEPs. The most actively involved in debates and most often using the recognition claims were MEPs from the centre and rightwing party groups in the EP - UEN, Ind/Dem, EPP-ED and ECR. The MEPs from ALDE and PES participated in these debates much less frequently and used the recognition claims even less. This is in tune with the analysis of the historical politics on the national level. The MEPs using recognition arguments came from parties that were devoted to puruse historical politics on the domestic political scene, such as PiS, LPR and partially PO.

\section{Soviet Communism Equals Totalitarianism}

One of the main claims of CEE actors immediately after the end of the Cold War was (and still is) that the atrocities of the Nazi regime be treated equally with those of Soviet Communism. This argument still causes controversies in academic discussions and raises fervent debates among politicians in Europe.

The demand for equal treatment of the Nazi and Soviet regimes is often raised by Polish MEPs in debates in the EP. The main call is for Soviet Communism to be treated in Western European historiography and politics as totalitarianism, as should the crimes committed under this system. The second most often raised claim is recognition of the crimes under Soviet Communism as genocide. These claims mostly concern the period of the Second World War and its immediate aftermath. However, they also appear in the debate on commemoration of Holodomor in Ukraine before the war. It is also important to note that some MEPs have stressed that these demands do not diminish the significance of the Nazi crimes, especially the Holocaust, as sometimes alleged by their opponents, ${ }^{43}$ but rather that the recognition of the criminal character of any

\footnotetext{
42 Neumayer "Integrating".

43 Mälksoo, "The Discourse".
} 
totalitarian regime makes European societies more immune to its devastating effects. Finally, some MEPs demand recognition of specific crimes against the Polish nation which in their opinion are not properly known and commemorated, such as the Katyń massacre. Such claims are also obviously directed to the memory politics of Russia. It is important to note that even though some MEPs call for the EU to put pressure on Russia to deal with its past, most of them are actually very moderate in their demands toward Moscow and focus rather on the $\mathrm{EU}$ and its member states and societies.

These claims are predominantly about 'inclusion of their [CEE societies] wartime experiences in the currently West-European bent understanding of the implication and ramification of this war. ${ }^{44}$ In many ME Ps' statements, their claims have a universalistic, European motivation. As one of them argued, 'individual nations had very different experiences of the Second World War, and so the debate we are holding today is perhaps the most important debate on European identity that has been held for years. If we genuinely wish to join together to form a single European spiritual community, we must all endeavour to gain a full understanding of the historical experiences of Europe's nations. In order to do so, there are certain issues about which we must speak quite frankly'45 According to Polish political actors, a European identity suitable for the societies of old and new member states is at stake, as are European values. The main motivation expressed for the recognition of the totalitarian nature of Soviet Communism is, generally speaking, a common future in the EU. One of the MEPS from UEN argued, "The building of a democratic Europe is possible only on the foundations of truth, including the truth about anti-human communist totalitarianism. We owe remembrance and justice not only to the victims of inhuman systems; first of all we owe it to present and future generations so that this situation does not happen again.46 Many MEPs claim that this recognition should be granted in order to create a sense of belonging in the community. Another frequently raised motivation deals with European values: 'The more Europeans know about the true face of totalitarianism, the better it

\footnotetext{
44 Ibid. 2.

45 Wojciech Roszkowski (UEN), "The future of Europe sixty years after the Second World War", European Parliament plenary debate (11 May 2005) accessed August 2014, http:// www.europarl.europa.eu/sides/getDoc.do?pubRef=-02f\%2fEP\%2f\%2fTEXT\%2bCRE\%2 b20050511\%2bITEM-016\%2bDOC\%2bXML\%2bVo\%2f\%2fEN\&language=EN.

46 Mirosław Piotrowski (UEN), "Proposed hearing of the Commission on crimes of genocide, crimes against humanity and war crimes committed by totalitarian regimes" European Parliament plenary debate, (21 April 2008), accessed August 2014, http://www.europarl .europa.eu/sides/getDoc.do?pubRef=-\%2f\%2fEP\%2f\%2fTEXT\%2bCRE\%2b20080421\%2 bITEM-015\%2bDOC\%2bXML\%2bVo\%2f\%2fEN\&language=EN.
} 
will be for the future of the European Union. This is not a matter of celebrating the sufferings of millions of people. It is about understanding the dramatic consequences which came from and are still coming from totalitarian practices in many countries in Europe. Solidarity, freedom, empathy, toleration, dialogue - all of these values look somewhat different if we look at them from the perspective of experiences with totalitarianism. Let us remember this.' ${ }^{47}$

Another interesting aspect of the analysis of Polish MEPs' claims is to whom they direct their demands. Most often, it is Western Europe in general and its societies. Less frequently - and specifically in cases of concrete instruments of commemoration - it is EU institutions, especially the European Commission, that are the addressees of the claims. In a few instances - predominantly by MEPs from centre- and right-wing party groups - the political opponents are addressed. Specifically, claims about the totalitarian nature of Soviet Communism are frequently directed to the European Left, whom some right-wing MEPs believe relativizes the crimes of Communism for ideological reasons: 'Whoever today relativises the criminal character of totalitarianism, be it Nazi or Communist totalitarianism, stands in opposition to the traditions of a country ruled by law and to democracy. It is, by the way, characteristic that while the European Right does not relativise Nazi crimes today, the European Left does relativise Communist crimes. ${ }^{48}$ However, also voices from the Left itself albeit very few - raise this problem. As a Polish MEP from the PES declared: 'We are opposed to the manipulation of that memory, and to the insulting of that memory, where it is used today in an ideological battle, in a party fight in the European political system. We remember the victims. The victims of 2oth-century totalitarian regimes must be the foundation of today's democracy in Europe. 49

The claims for recognition of the significance of the crimes of Soviet Communism, especially during the Second World War, serve a double purpose for MEPs from Poland. Firstly, it equates the CEE experience with that of Western Europe, and therefore combats the Orientalist, essentially colonial approach of Western Europeans to this experience..$^{50}$ As a result, it paves the way for an equal position in the EU, making this experience equally important

47 Filip Kaczmarek (PPE-DE), "European conscience and totalitarianism” European Parliament plenary debate (25 March 2009) accessed August 2014, http://www.europarl.europa .eu/sides/getDoc.do?pubRef=-//EP//TEXT+CRE+20090325+ITEM-o10+DOC+XML+ Vo//EN.

48 Wojciech Roszkowski (UEN), "European conscience".

49 Józef Pinior (PSE), "European conscience".

5o Mälksoo, "The Discourse". 
and therefore serving the emerging European identity and community of the new, united Europe. Secondly, this reaffirms their own identity as fully-fledged Europeans and secures their place in the Eu. This is also visible in less dramatic debates on the experience of living under Communism and fighting its system.

The reception of such claims resonates with its prime purpose of achieving an equal position within the community. Frequently the claims are positioned as justified. As one of the MEPs stated: 'the history of central and eastern Europe is our history. The problem for us British and for us French is that we were Stalin's allies at the end of the War. It took 30 years for the British to admit that Katyn was a Stalinist crime.'51 It is important to note that especially EPP politicians used the term of Stalinist totalitarianism in their statements: 'Although National Socialist totalitarianism was vanquished in 1945, Stalinist totalitarianism divided Europe and imposed its unjust rule on the peoples of Central, Eastern and South-Eastern Europe. Hope, though, did not desert the less happy survivors of the Second World War - the hope of a shared Europe, intellectually, morally and politically renewed, with the prospect of prosperity for all its citizens. To this hope they eventually gave shape in a peaceful revolution, the watchword for which was Solidarnosc.52 That is consistent with findings of scholars analyzing the process of mnemonic entrepreneurship that was especially successful within EPP. ${ }^{53}$

However, representatives for the radical left-wing party group (GUE/NGL) fiercely opposed during the analyzed debates, not the recognition of Stalinism as totalitarianism, but rather - in the words of an GUE/NGL MEP - 'the attempt surreptitiously to trivialise Nazism by placing it in a generic category that includes, in particular, Stalinism and even the regimes existing in central and eastern Europe prior to the fall of the Berlin Wall. ${ }^{54}$ Such arguments especially expressed by far left parties - have not changed much over time. They were reflected in the interparty conflicts as EPP MEP stressed: 'there is a further dimension to this debate. It is not only a united Europe that needs urgently to look at the entirety of the past, but the same is particularly true of the European Left'.55

\footnotetext{
$5^{1} \quad$ Christopher Beazley (PPE-DE), "Proposed hearing".

52 Hans-Gert Pöttering (PPE-DE), "The future of Europe".

53 Neumayer "Integrating".

54 Francis Wurtz (GUE/NGL), "Proposed hearing".

55 Gyorgi Schöpflin (PPE-DE), "European conscience”.
} 


\section{Who Ended the Cold War and Why Does it Matter?}

A very frequent claim raised by Polish MEPs regards the significance of the experience of the opposition struggles in Poland under Communism for a united Europe. This is specifically visible when the Solidarity movement is mentioned in the EP. The main argument raised by Polish MEPs deals with the universality of values for which the Solidarity movement fought, as well as their complementarities with Western European values. The main claim was predominantly about the recognition of Poles as part of the same European family. This was - as discussed above - a concurrent theme in the discourse on the EU enlargement in Poland. It was mostly about how, due to their religion, history and values, Poles belong to the Western European civilization.

One element in statements on the Solidarity movement raised by Polish MEPS seems very interesting in the context of this chapter. It is connected with the claim for recognition of the significance of the Solidarity movement and its demands from 1980 for global, or at least European, historical processes. According to Polish MEPs, it was not Hungarian or Czech attempts to overthrow the Communist regime, nor the German demolition of the Berlin Wall which ultimately ended Communism in CEE and the world. It was the Polish Solidarity movement and its unprecedented mobilization of the people that finally became decisive. As one of the MEPs put it, 'Solidarity was instrumental in much more besides. It led to the peaceful revolution in Central and Eastern Europe. Nine years after the so-called outbreak of Solidarity, Czechoslovakia underwent the Velvet Revolution, and the fall of the Berlin Wall followed. The origins of these events can, however, be traced back to 1980 and to Gdansk, in Poland'.56 Such a position in the debate signals the need not yet fully expressed by Polish MEPs to be recognized in the Western European family as significant actors who contributed greatly to the changes in the continent. Various analyses of the Polish discourse on the Second World War highlight the collective trauma of being betrayed, left alone beyond the Iron Curtain. Passivity is alien to the Polish political and strategic culture since, at least from the period of partition, it was always important to act against the will of the stronger, rather than passively wait for a fate which was decided above their heads. This resonated in Polish politics in the interwar period and has returned with

$5^{6}$ Ryszard Czarnecki (NI), "25th Anniversary of Solidarity and its message for Europe" European Parliament plenary debate (26 September 2005) accessed August 2014, http://www.europarl.europa.eu/sides/getDoc.do?pubRef=-//EP//TEXT+CRE+ 20050926+ITEM-013+DOC+XML+Vo//EN. 
double strength since $1989 .{ }^{57}$ The Solidarity movement and its achievements are specifically important because they undo the curse of the Yalta conference. One MEP made it clear: 'Attempts had been made previously by the Czechs, Slovaks and Hungarians to overthrow that diabolical system, but it was the Poles and the Polish Pope who eventually succeeded in dismantling the agreements reached at Yalta. 58

The recognition of the constant Polish fight with Communism, which culminated during the Solidarity period, serves two main purposes for Polish MEPs. First and foremost, as stated above, it is about finding a place in the European Community and becoming a fully-fledged member thereof. This is done through claiming a strong commitment to the most important values of Europe. It is important to stress that the special experience of CEE societies under Communism, with their then much more caucious attitude towards any idealistic, utopian project and yet the particular attention to the individual freedom and liberty of which they were long deprived, could enrich the reflections on the future of Europe. Secondly, assertions about the contribution of Solidarity (and the broader Polish struggles with Communism) to the European peace after the Cold War are connected with redistribution claims. As will be discussed in the next part of the paper, assuring an equal place in community allows demands connected with fair distribution of goods.

The analysis of the reception of such claims confirms that Solidarity occupies an important place in the collective memory of the united Europe and that it was strengthened through the Polish political actors' claims. It has also been frequently asserted that the values that the Solidarity movement represented are important for European heritage: 'Solidarity symbolised then, as it does now, hope in the future, the determination of people to build better lives for themselves and their families and an unshakeable belief in the power of the human spirit'.59 However, the second function of the claims, i.e. the redistribution claims finds less response in the analyzed material. In other words, Solidarity is widely perceived, in a symbolic sense, as a significant contributor to the European experience. However, it has not yet been translated into the acceptance of the right of claimants to demand a different position as regards redistribution. That will be further elaborated in the following section of the chapter.

57 Góra, Mach, "Between Old Fears".

58 Jan Masiel (NI), "25th Anniversary".

59 Timothy Kirkhope (PPE-DE), "25th Anniversary”. 


\section{This is Why You Need to Pay}

The claims for the recognition of the experience of Communism also serve other purposes. As mentioned in the theoretical part of this paper, Nancy Fraser argues that part of the struggles for recognition is the right to be treated equally when redistribution is in question. Following this line of argumentation, some claims for the recognition of the experience of Communism provide political actors with the necessary instruments to demand either special treatment under Eu law or to bargain for redistribution.

The case of the Polish shipyards was one of the most difficult and complicated issues. The European Commission stood against the Polish government for its non-compliance with competition law since it was heavily subsidizing shipyards in Gdańsk, Gdynia and Szczecin. At the same time, this particular industrial sector occupies a special place in the Polish experience, as these were the cradles of opposition against Communist rule, and specifically the Solidarity movement. The long negotiations between the EC and Polish government proved to be extremely difficult, and the debate finally entered the European Parliament in 2007 and 2008. Ultimately, the EC and Commissioner Neelie Kroes decided against the subsidies of the Polish shipyards, arguing that state aid was illegal.

Most of the arguments in the debates were of an economic and political nature; however, many MEPs used arguments that pointed to the special character and symbolic meaning of the shipyards, and therefore the right to special treatment of them. As one of the MEPs stressed, "The Gdansk Shipyard, the cradle of solidarity, the chief actor in the struggle against communism, a shipyard which suffered discrimination and which by the political decisions of the communists was brought to a poor financial condition, today awaits a positive decision from the European Commission' ${ }^{60}$ The crucial argument for the anticipated special treatment was that the sector had already been destroyed by the Communist economy, and that an attempt to save it was just and appropriate. Moreover, according to some MEPs, the entire EU owes its current well-being and prosperity to the struggle of workers under Communism: 'Polish shipyards, particularly the Gdansk shipyard, are a symbol of the struggle against the Communist government. They symbolise the fall of the Iron Curtain which had divided Europe in two. That is why the flagpoles, which stand outside the European Parliament buildings, and which fly flags of the Member

6o Elżbieta Tomaszewska (UEN), "Reform programme of Polish shipyards" European Parliament plenary debate (21 October 2008) accessed August 2014 http://www.europarl. europa.eu/sides/getDoc.do?pubRef=-\% 2f\%2fEP\%2f\%2fTEXT\%2bCRE\%2b20081021\%2 bITEM-016\%2bDOC\%2bXML\%2bVo\%2f\%2fEN\&language=EN. 
States, were made in the Gdansk shipyards. It is thanks to the heroic actions of Polish shipyard workers, who fought for a re-united Europe, that today we are able to meet here together. These people deserve our respect, they deserve a dignified life and a decent living' ${ }^{61}$

In the discussed debates dealing with the issues of redistribution, the topic of the recognition of past experience appears much less frequently. The main arguments link the lower level of development in former communist countries and the need for greater solidarity with the Cold War division of Europe. In special circumstances - such as in the case of the Polish shipyards - the role in the historical processes of the continent is perceived as an appropriate justification for special treatment in contemporary European politics.

The symbolic significance of shipyards was recognized in the debates although the prime interest was the economic aspects of the conflict. The leader of PES stated ultimately that 'The Polish shipyards, sites such as Gdansk and Szczecin, were an important symbol for us all, of the Polish people's democratic struggle against dictatorship. That is another reason why these yards must not be closed'. ${ }^{62}$ However, the claims that the experience of Communism and its economic heritage could be used as an argument for the non-compliance with EU regulations, were not supported. The reception of such claims was different predominantly due to the explicit, individual - often clearly economic - interest behind the demands. The case of shipyards confirms that, as much as there is an economic heritage of Communism with which new member states are struggling, it is not widely perceived as an excuse for different treatment.

\section{Conclusions}

The progress of European integration, and also the enlargement in which former communist countries joined the $\mathrm{E} \mathrm{U}$, has created a new, much broader and demanding frame of reference within which the European politics of memory and recognition can be developed. The European, enlarged space of historical debate has also become a frame for the construction of collective identities. As identity is a process of dialogue, an interaction with 'significant others', an involvement in meaningful relations with partners, the enlarged Europe has become a place of struggle for the recognition of those who have previously, in the divided Europe, not participated in the process of the construction of

\footnotetext{
61 Adam Bielan (UEN), "Reform programme".

62 Martin Schultz (PSE), "Reform programme".
} 
European memory and identity. For Poland and its people, as for other new members of the $\mathrm{EU}$, it has become crucial to make themselves heard and respected in their memories and interpretations of the past. The struggle for recognition consists in an attempt to introduce new topics into the European discourse - those which did not exist before 1989 or were only in the margins. The demand is that particular national or regional historical experiences and memories should become recognized by all Europeans and represented in mainstream European narratives. Also, Central and Eastern Europeans have tried to win recognition of their interpretations of events and processes which already exist in European memory.

It seems - based on our analysis - that the success of the struggle for recognition depends on whether Central and Eastern Europeans are able to offer their own, new interpretation of those issues which are seen as essential for the whole of Europe and not only for the region of CEE. The key problem here, however, is that new members of the EU must, in order to be accepted as equal partners in the dialogue, in order to be recognized, speak a language which is understood and respected. The concepts, metaphors, symbolic references and emotional expressions used in communication create the impression of familiarity or alienation. It is therefore important that new members of the network of communication know, understand and learn to use the language which is seen as the idiom of the European common platform of dialogue. Our analysis shows that the plenary sessions of the EP has served as a forum to express claims directed to Western Europe in its broadest sense and its societies. The EU institutions have been much less frequently addressed with such claims. Moreover, the main motivations given for such claims have been predominantly universally European, referring to European values and the future of European integration.

In order to be successful in their struggle for recognition, the new member states also need to address issues, questions and problems which are important for Europe and promise to contribute something to European common understanding. Our analysis shows that the new members have been able to introduce new topics of discussion which are seen as an important contribution to the common European heritage. Their voice is heard and their experience at least partially recognized. In particular, former communist countries will be recognized as equal if they can demonstrate not only that the experience of communism is important for them, but that it is important for the whole of Europe. As visible in our analysis, they have rather quickly learnt how to frame their demands. The well-being of Europe and the EU, as well as European values and principles, have often been used in the justifications of Polish MEPS and that has resonated well in the EP. 
Finally, we argue that the EU has become - even if only partially - a new recognition order for political actors from Poland. It has become a significant place for claims related to identity as well as for redistribution. The debates on the Polish shipyard sector show how the recognition of historical experience can be utilized in political battles to receive special treatment, in this context connected with the economic aspects of integration.

\section{Bibliography}

Closa, Carlos. "Negotiating the Past: Claims for Recognition and Policies of Memory in the EU". Working Paper. Instituto de Políticas y Bienes Públicos (IPP), ccHS-csIC, 8 (2010). http://ipp.csic.es/en/workpaper/negotiating-past-claims-recognitionandpolicies-memory-eu (accessed August 2014).

European Parliament plenary debate. "25th Anniversary of Solidarity and its message for Europe" (26 September 2005). Accessed July 2014. http://www.europarl.europa.eu/sides/getDoc.do?pubRef=-//EP//TEXT +CRE +20050926+ ITEM-013+DOC+XML+Vo//EN.

European Parliament plenary debate. "The future of Europe sixty years after the Second World War", (11 May 2005). Accessed July 2014. http://www.europarl.europa .eu/sides/getDoc.do?pubRef=-\%2f\%2fEP\%2f\%2fTEXT\%2bCRE\%2b20050511\%2bI TEM-016\%2bDOC\%2bXML\%2bVo\%2f\%2fEN\&language=EN.

European Parliament plenary debate. "Proposed hearing of the Commission on crimes of genocide, crimes against humanity and war crimes committed by totalitarian regimes", (21 April 2008). Accessed July 2014. http://www.europarl.europa.eu/ sides/getDoc.do?pubRef=-\%2f\%2fEP\%2f\%2fTEXT\%2bCRE\%2b20o80421\%2bIT EM-015\%2bDOC\%2bXML\%2bVo\%2f\%2fEN\&language=EN.

European Parliament plenary debate "Reform programme of Polish shipyards" (21 October 2008). Accessed July 2014. http://www.europarl.europa.eu/sides/getDoc .do?pubRef=-\%2f\%2fEP\%2f\%2fTEXT\%2bCRE\%2b2oo81021\%2bITEM-016\%2bDO C\%2bXML\%2bVo\%2f\%2fEN\&language=EN.

European Parliament plenary debate. "European conscience and totalitarianism" (25 March 2009). Accessed July 2014. http://www.europarl.europa.eu/sides/getDoc .do?pubRef=-//EP//TEXT+CRE+20090325+ITEM-o10+DOC+XML+Vo//EN.

Fossum, John Erik. "Conceptualizing the EU's Social Constituency." European Journal of Social Theory 8:2 (2005): 123-147.

Fossum, John Erik, and Marit Eldholm. "Conceptualising (and tentatively mapping) the EU's social constituency". In Civic Resources and the Future of the European Union, edited by Ireneusz Pawel Karolewski, Viktoria Kaina, 146-195. London: Routledge, 2012. 
Fraser, Nancy. "Social Justice in the Age of Identity Politics: Redistribution, Recognition, and Participation". The Tanner Lectures on Human Values. Delivered at Stanford University, 30 April-2 May 1996.

Fraser Nancy, and Axel Honneth. Redistribution of recognition? A political-philosophical exchange. London, New York: Verso, 2003.

Góra, Magdalena. "Solidarity of Citizens and of States in the European Union," Visegrad Insight, 2:4 (2013) 21-24.

Góra, Magdalena, and Katarzyna Zielińska. "Defenders of faith? Victims of secularization? Polish politicians in the European Parliament." Religion, State, Society 42:2-3 (2014): 211-226.

Góra, Magdalena, and Zdzisław Mach. "Between Old Fears and New Challenges. The Polish Debate of Europe," in Justine Lacroix, Kalypso Nicolaïdis, (eds), European Stories. Intellectual Debates in National Contexts, 221-256. Oxford: Oxford University Press, 2010.

Gross, Tomasz J. Neighbors: the Destruction of the Jewish Community at Jewabne, Poland, Princeton: Princeton University Press, 2001.

Gross, Tomasz J. Fear: Anti-Semitism in Poland After Auschwitz. An Essay in Historical Interpretation, Princeton, Oxford: Princeton University Press, 2006.

Gutman, Amy. "Introduction". In Multiculturalism. The Examination the Politics of Recognition, edited by Amy Gutman, 3-24. Princeton, New Jersey: Princeton University Press, 1994.

Hellgren, Zenia and Barbara Hobson. "Gender and ethnic minority claims in Swedish and Eu frames. Sites of Multilevel Political Opportunities and Boundary Making”. In Gender politics in the expanding European Union: mobilization, inclusion, exclusion, edited by Silke Roth, 211-237. New York, Oxford: Berghahn Books, 2008.

Honneth, Axel. The Struggle for Recognition: The Moral Grammar of Social Conflicts, Cambridge: Polity Press, 1995.

Honneth, Axel. "Redistribution as Recognition: A Response to Nancy Fraser". In Nancy Fraser, Axel Honneth, Redistribution of recognition? A political-philosophical exchange, London, 110-197. New York: Verso, 2003.

Honneth, Axel. "Recognition and Justice: Outline of a Plural Theory of Justice." Acta Sociologica 47:4 (2004): 351-364.

Kaczyński, Jarosław. "Wypowiedź w debacie”, in Informacja rządu na temat polskiej polityki zagranicznej w 2003 roku. 4 kadencja, 40 posiedzenie, 2 dzień (22 January 2003), http://orka2.sejm.gov.pl/Debata4.nsf (accessed August 2014).

Kattago, Siobhan. "Memory, Pluralism and the Agony of Politics." Journal of Baltic Studies, 41:3 (2010): 383-394.

Killingsworth, Matt, Małgorzata Klatt, and Stefan Auer. "Where Does Poland Fit in Europe? How Political Memory Influences Polish MEPs' Perceptions of Poland's place in Europe." Perspectives on European Politics and Society, 11:4 (2010): 358-375. 
Krasnodębski,Zdzisław. Demokracja peryferii. Gdańsk: Wydawnictwo słowo/obraz terytoria, 2005.

Lazzeri, Christian, and Alain Caillé. "Recognition Today. The Theoretical, Ethical and Political Stakes of the Concept". In Recognition, Work, Politics. New Directions in French Critical Theory, edited by Jean-Philippe Deranty, Danielle Petherbridge, John Rundell, Robert Sinnerbrink, 89-126. Leiden, Boston: Brill, 2007.

Letki, Natalia. "Lustration and Democratisation in East-Central Europe." Europe-Asia Studies 54:4 (2002): 529-552.

Mälksoo, Maria. "The Discourse of Communist Crimes in the European Memory Politics of World War II". Paper presented at the Ideology and Discourse Analysis conference 'Rethinking Political Frontiers and Democracy in a New World Order', Roskilde University, Denmark, 8-10 September 2008.

Mazowiecki, Tadeusz. "Wnioski Prezydenta PRL o odwołaniu ze stanowiska Prezesa Rady Ministrów Czesława Kiszczaka oraz o powołanie na stanowisko Prezesa Rady Ministrów Tadeusza Mazowieckiego", in Sejm Rzeczpospolitej Polskiej X Kadencji, Sprawozdanie Stenograficzne z 6 Posiedzenia Sejmu, 23 i 24 sierpnia 1989, Warszawa 1989, in http://orka2.sejm.gov.pl/StenogramyX.nsf/o/259278CD28DE3BBDC1257D2 0002CC6FD/\$file/oo6_ooooo6771.pdf (accessed August 2014).

Mink Georges, and Laure Neumayer. History, Memory and Politics in Central and Eastern Europe. Memory Games. Basingstoke: Plagrave Macmillan, 2013.

Neumayer, Laure. "Integrating the Central European Past into a Common Narrative: The Mobilizations Around the 'Crimes of Communism' in the European Parliament." Journal of Contemporary European Studies 23:3 (2015): 344-363.

Pękacz, Joanna. "'Antemurale of Europe'. From the History of National Megalomania In Poland." History of European Ideas 20:1-3 (1995): 419-424.

Sanford, Georges "Overcoming the Burden of History in Polish Foreign Policy." Journal of Communist Studies and Transition Politics 19:3 (2003): 178-203.

Stola, Dariusz. "Poland's Institute of national Remembrance: A Ministry of Memory?". In The Convolutions of Historical Politics, edited by A. Miller, M. Lipman, 45-58. Budapest: Central European University Press, 2012.

Stan, Lavinia (ed.). Eastern Europe and the Former Soviet Union. Reckoning with the communist past. London: Routledge, 2009.

Taylor, Charles. "The Politics of Recognition". In Multiculturalism. The Examination the Politics of Recognition, edited by Amy Gutman, 25-74. Princeton, New Jersey: Princeton University Press, 1994.

Tazbir, Janusz. “Europejska wspólnota obronna”. In Europa. Drogi integracji, edited by Aniela, Dylus. Warszawa: Studium Generale Europa, Uniwersytet Kardynała Stefana Wyszyńskiego, 1999.

Tully, James. "Struggles over Recognition and Distribution," Constellations 7:4 (2000): 469-482.

Ujazdowski, Kazimierz M. "Wypowiedź w debacie”. In Informacja Ministra Spraw Zagranicznych o zadaniach polskiej polityki zagranicznej w 2005 roku, 4 kadencja, 
96 posiedzenie, 3 dzień (21 January 2005) http://orka2.sejm.gov.pl/Debata4.nsf (accessed August 2014).

Williams Kieran, Aleks Szczerbiak, and Brigid Fowler. "Explaining Lustration in Eastern Europe: 'A Post-communist politics approach”. SEI Working Paper 62 (2003), https://www.sussex.ac.uk/webteam/gateway/file.php?name=sei-working-paperno-62.pdf\&site=266 (accessed August 2014).

\section{Annex 1. List of Analyzed Plenary Debates in the European Parliament}

European Parliament plenary debate. "Anti-semitism and racism" (25 January 2005), http://www.europarl.europa.eu/sides/getDoc.do?pubRef=-\%2f\%2fEP\%2f\%2fTEX T\%2bCRE\%2b20050126\%2bITEM-008\%2bDOC\%2bXML\%2bVo\%2f\%2fPL\&langu age $=$ PL\&query $=$ INTERV \&detail $=3-149$.

European Parliament plenary debate. "The future of Europe sixty years after the Second World War", (11 May 2005). Accessed July 2014. http://www.europarl.europa .eu/sides/getDoc.do?pubRef=-\%2f\%2fEP\%2f\%2fTEXT\%2bCRE\%2b20050511\%2bI TEM-016\%2bDOC\%2bXML\%2bVo\%2f\%2fEN\&language=EN.

European Parliament plenary debate. "25th Anniversary of Solidarity and its message for Europe” (26 September 2005). http://www.europarl.europa.eu/sides/getDoc .do?pubRef=-//EP//TEXT+CRE+20050926+ITEM-013+DOC+XML+Vo//EN.

European Parliament plenary debate. "Culture 2007" (24 October 2005). http://www .europarl.europa.eu/sides/getDoc.do?pubRef=-//EP//TEXT+CRE+20051024+ ITEM-016+DOC+XML+Vo//EN.

European Parliament plenary debate. "The Human Rights and democracy clause" (14 February 2006). http://www.europarl.europa.eu/sides/getDoc.do?pubRef=-\%2f\%2f EP\%2f\%2fTEXT\%2bCRE\%2b20o6o214\%2bITEM-004\%2bDOC\%2bXML\%2bVo\%2 $\mathrm{f} \% 2 \mathrm{fEN} \&$ language $=\mathrm{EN}$.

European Parliament plenary debate. "Citizens for Europe Programme (2007-2013)" (4 April 2006). http://www.europarl.europa.eu/sides/getDoc.do?pubRef=-\%2f\%2f EP\%2f\%2fTEXT\%2bCRE\%2b20060404\%2bITEM-015\%2bDOC\%2bXML\%2bVo\%2 f\%2fEN\&language $=\mathrm{EN}$.

European Parliament plenary debate. "Risk of closure of Gdansk shipyard" (4 September 2007). http://www.europarl.europa.eu/sides/getDoc.do?pubRef=-\%2f \%2fEP\% 2f\%2fTEXT\%2bCRE\%2b20070904\%2bITEM-005\%2bDOC\%2bXML\%2bVo\%2f\%2 fEN\&language $=\mathrm{EN}$.

European Parliament plenary debate. "Proposed hearing of the Commission on crimes of genocide, crimes against humanity and war crimes committed by totalitarian regimes" (21 April 2008). http://www.europarl.europa.eu/sides/getDoc.do?pubRef=\%2f\%2fEP\%2f\%2fTEXT\%2bCRE\%2b20o80421\%2bITEM-015\%2bDOC\%2bXML\% 2bVo\% $\%$ f $\% 2 \mathrm{fEN} \&$ language $=\mathrm{EN}$. 
European Parliament plenary debate "Reform programme of Polish shipyards" (21 October 2008). http://www.europarl.europa.eu/sides/getDoc.do?pubRef=-\%2f\%2f EP\%2f\%2fTEXT\%2bCRE\%2b20081021\%2bITEM-016\%2bDOC\%2bXML\%2bVo\%2f $\%$ 2fEN\&language $=\mathrm{EN}$.

European Parliament plenary debate. "Commemoration of Holodomor" (22 October 2008). http://www.europarl.europa.eu/sides/getDoc.do?pubRef=-\%2f\%2fEP\%2f\% 2fTEXT\%2bCRE\%2b20081022\%2bITEM-014\%2bDOC\%2bXML\%2bVo\%2f\%2fEN \&language $=\mathrm{EN}$.

European Parliament plenary debate. "European conscience and totalitarianism" (25 March 2009). http://www.europarl.europa.eu/sides/getDoc.do?pubRef=-//EP// TEXT+CRE+20090325+ITEM-010+DOC+XML+Vo//EN. 